\title{
Indonesian Horror Film: Deconstruction of Repetitive Elements of Indonesian Urban Legend for Cultural Revitalization, Creativity, and Critical Thinking
}

\section{Diki Tiwahyupriadi and Yulia Ayuningtyas}

Fine Art Education, State University of Surabaya Surabaya, Indonesia

\section{Abstract}

Currently, film remains the main media for public entertainment. Of the many genres of film in Indonesia, horror is still the most popular. Unfortunately, Indonesian horror films pay little attention to the creative aspects of the story but focus on cinematography, producing repetitive performances which often follow stock templates. The story typically begins with moving to an empty house, getting lost in the forest, and being haunted by female ghosts. Even so, horror films like this are required to encourage critical and creative thinking of observers and film producers. Therefore, this study

Corresponding Author: Diki Tiwahyupriadi tdiki36@gmail.com

Received: Month 2020 Accepted: Month 2020 Published: Month 2020

Publishing services provided by Knowledge E

(c) Diki Tiwahyupriadi and Yulia Ayuningtyas. This article is distributed under the terms of the Creative Commons

Attribution License, which permits unrestricted use and redistribution provided that the original author and source are credited.

Selection and Peer-review under the responsibility of the ICADECS Conference Committee. aims to discuss the disruptive element through repetitive stories in horror films that are able to open up opportunities for the emergence of creative interplay and its relevance to creative education through horror films in Indonesia. This research uses Maruska Svasek's perspective on transit and transition which will dissect cultural phenomena in Indonesian horror films. In addition, the viewpoint from Derrida is used to deconstruct repetitive thoughts by film audiences to show the demythologization that occurs in current horror films. Data is taken from literature studies of Indonesian horror films with temporal limitations 2017-2019. Data was also collected using a questionnaire with the decoding-encoding belonging to Stuart Hall perspective. The results of the study show that the repetitive story culture is caused by Indonesian people's interest in legendary urban legend stories. Utilizing urban legend as the main idea of the story, through Svasek's perspective, creates attention to the culture that provides an opportunity for cultural preservation and revitalization.

Keywords: Indonesian horror film, urban legend, deconstruction, cultural revitalization, creativity.

\section{Preliminary}

The development of the film was very rapid, starting with the discovery of the pinhole camera, then followed by a camera obscura around 1021 which allows moving images but does not record. (Sugiharto,2013). In the 1830s moving images began to be produced through a device invented by Simon von Stampfer, then Josephplateu, 
William Horner, Eadweard Muybridge, Etienne-Jules Marey, Charles Francis, and finally Louis and Auguste Lumiere gave birth to a standard tool capable of displaying images lived in 1895, with its instrument known as cinematography. This tool was later refined by Dickson and Edison with their invention of the celluloid band in 1893. (Marvelous Cinematograph, 1894).

The film now spreads to all areas of human life. And almost everyone now has the opportunity to make their films, thanks to the support of technology that is also developing with its increasingly portable form such as cellphones, tablets, laptops, cameras, etc.

In the field of art itself, film is a phenomenon whose presence is very strong, simultaneously - about other fields of art - its position is very paradoxical. On the one hand, the film utilizes and summarizes all other fields of art (art, sculpture, literature, dance, music, etc.), like a black hole that engulfs everything in itself; on the other hand, the film is actually able to also expose, underline or strengthen the field of art other arts dramatically (Sugiharto,2013).

Since its entry into Indonesia in the 1900-1920s, films have always experienced ups and downs. Reporting from beritasatu.com, (27/01/2018) 2018 could be the year of Indonesian films. This can be assessed from fairlyconsistent developments. When viewed from the number of viewers recorded in 2016 to 2017.

One genre of film, namely horror films become a magnet for film lovers in the homeland because according to one psychoanalysis, (Sigmund Freud) horror is about the latent desires of humans under the conscious mind.

But unfortunately, Indonesian horror films seem more repetitive and pay less attention to aspects of the story. The story begins with moving house, in an empty house, lost in the forest, victimizing, until a ghost who is always a woman to be a little example of repetition in the horror film in Indonesia.

This phenomenon becomes interesting to do in-depth observations to find out how the repetitive element of Indonesian horror films as a medium of reflection and encourage critical and creative thinking. So that it can provide opportunities for cultural preservation and revitalization.

To discuss and dissect the question the writer uses the theory of Maruska Svasek about transit and transition, then the viewpoint of Derrida is also used to deconstruct repetitive thinking by film viewers to demonstrate the demythologization that occurs in horror films today. 


\section{Research Methods}

The method used in this research is a literature study. This method is very helpful because horror films can only be watched through electronic media.

The research method used is the study of literature on horror films through Cincrybe's YouTube account and the comments that appear in the comments column. Also, a direct review of horror films that aired in 2017-2019. Online questionnaires are also used to find out how people's opinions and tastes are about Indonesian horror films.

In this study using the theory of transit and transition by Maruska Svasek to dissect about the culture of Indonesian horror films. Deconstruction theory by Derrida is also used to deconstruct repetitive thinking by film viewers to demonstrate the demythologization that occurs in horror films today. Decoding encoding from Stuart Hall is used to analyze data from questionnaires that have been distributed during July 2019 .

\section{Discussion}

The first horror film released in Indonesia was titled Doea Siloeman Oelar Poeti en Item 1934, directed by Then Teng Chun. This film is about two demons who want to be human. then horror films developed rapidly. After the film, Terang Boelan produced by Nederlands Indie Film Syndicate with director Albert Balink.

But the horror film lost its charm and shone again in 1971. This became the beginning of Suzanna's debut with the film Beranak dalam Kubur which produced huge profits. Then many horror films were produced in 1976-1991.

The exploitation of female sexuality also colored Indonesian horror films in the 19701990s. And increasingly crazy in the 2000s. Even foreign porn artists become actors in Indonesian horror films. On the other hand, scary places also became the concept of Indonesian horror films that year.

Entered in 2017 Horror films began to dispel the impression of pornography which is closely related to horror films in previous years, marked by the emergence of the film Danur; I Can See Ghost (2017) and continued with Pengabdi Setan (2017) which is a remake of Pengabdi Setan (1982). This new concept of Indonesian horror films was enthusiastically welcomed by the public. This can be seen from the number of Pengabdi Setan's (2017) viewers which reached 1.2 million viewers.

Then also, Indonesian horror films pay less attention to the creative aspects of the story, but rather to the storyline, cinematography, and repetitive performances, even impressed "template". For example, the story that begins with moving house, empty 
house, lost in the forest, setting the night time that seems longer than in the afternoon, until victimizing. Of the 23 horror films released in 2017, there are at least 7 horror films whose stories are in an empty house. Like the film titled Ular Tangga and Jailangkung.

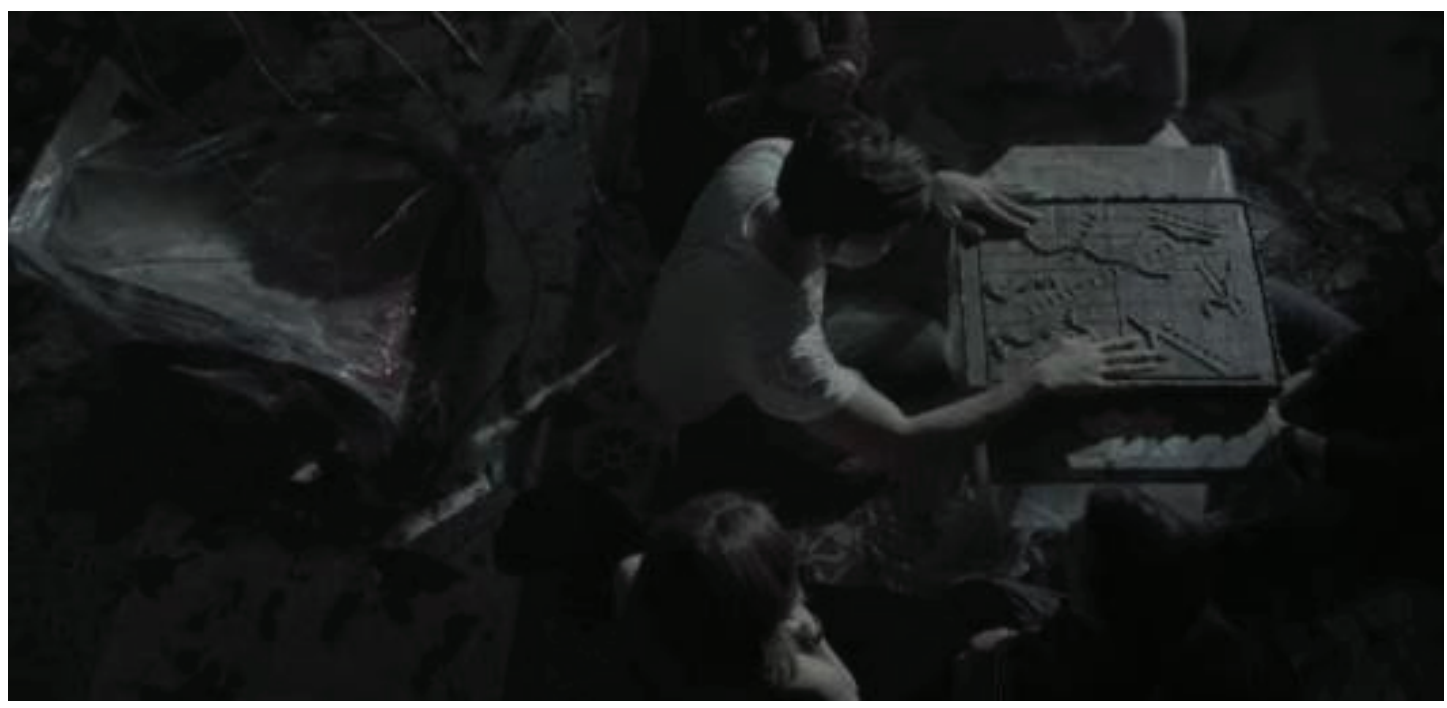

Figure 1: Empty House Scene on Ular Tangga Film

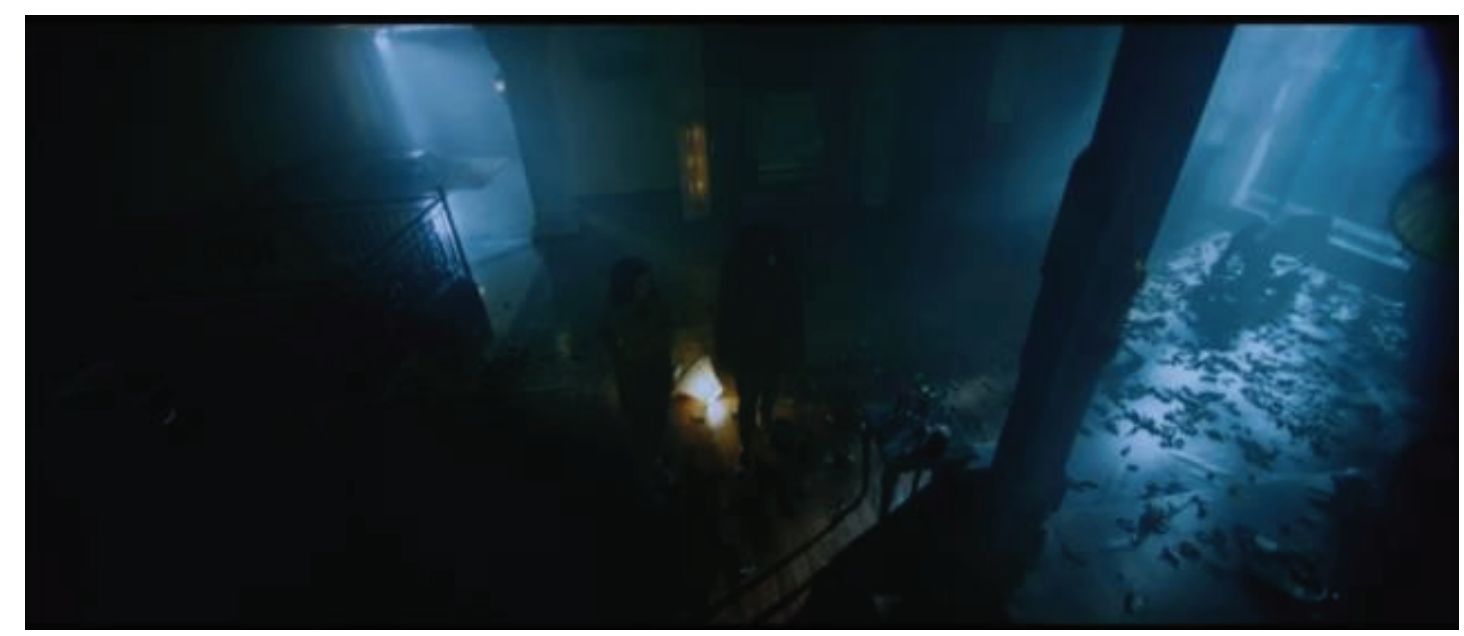

Figure 2: Scene of Empty House in Jailangkung Film

\subsection{Transit and Transition of Repetitive Elements of Indonesian Horror Films}

Maruska Svasek's perspective on transit and transition is in his book Anthropology, Art and Cultural Production. Transit and transition are processes that are expressed by Svašek as follows:

"Transit records the location or movement of objects overtime and across social or geographic boundaries, while transition analyses how the meaning, 
value and status of those objects, as well as how people experience them, is changed by that process" (Svašek, 2007: 4).

From the explanation above, transit is the process of moving an object (artwork) that can cross the geographical boundaries of the region to its social boundaries. While the transition is more to the process ofchange that exists in the value and meaning of the object (artwork).

Indonesian horror films with repetitive elements have an interesting side to discuss. One of the interesting things is about the process of removing cultural phenomena from people's lives which are then packaged in Indonesian horror films. On this basis, the authors conducted a qualitative study through digital questionnaires, namely google forms. From the questionnaire the authors get the following data:

\section{Rentang Usia Anda}

48 responses

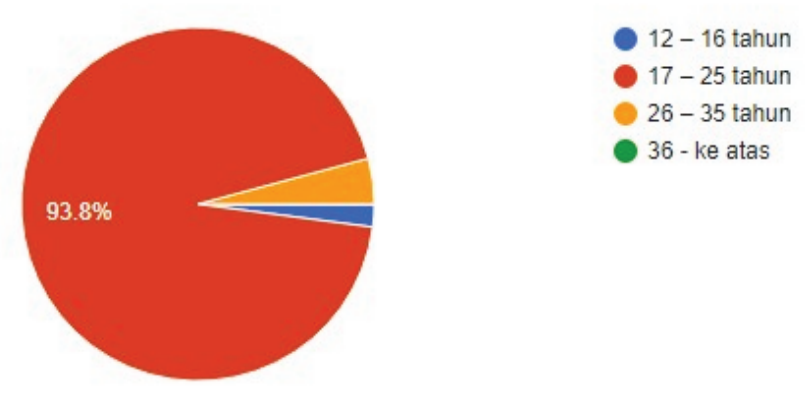

Figure 3: Data Age for Questionnaire Fills

\section{Profesi}

48 responses

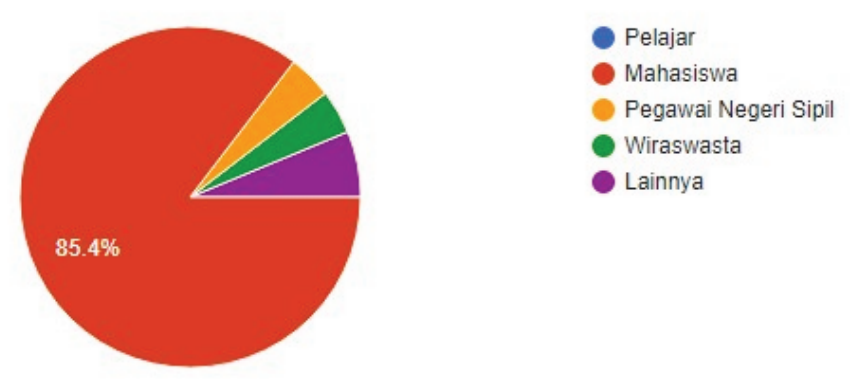

Figure 4: Questioner Filling Profession Data

Of the 48 respondents, as many as $93.8 \%$ of ages $17-25$ years, $4.2 \%$ of ages 26 25 years, $2.1 \%$ of ages $12-16$ years, and $0 \%$ of ages 36 years and over. Based on the 
Apa film horor Indonesia favorit anda sepanjang 2017-2019

48 responses

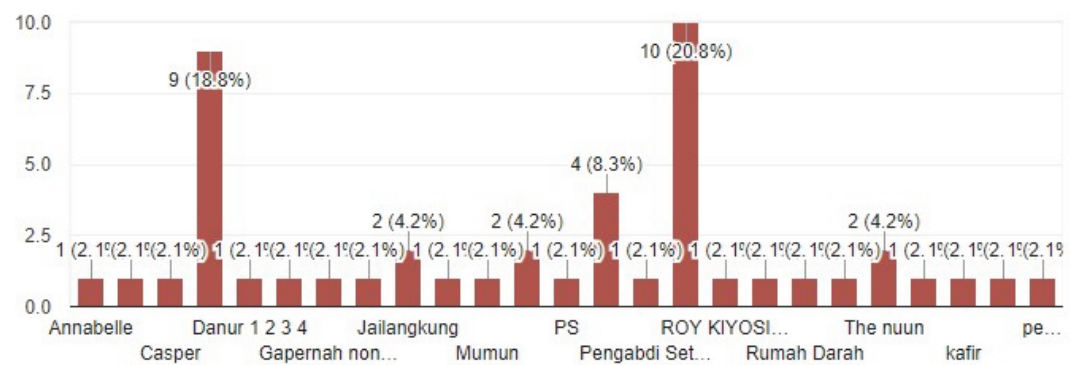

Figure 5: Favorite Horror Films Questionnaire Filler

profession, students become the profession that dominates respondents namely $85.4 \%$, followed by other professions of $6.3 \%$, and Civil Servants and Students respectively 4.2\%. The diagram above shows that Pengabdi Setan (2017) become favorite Indonesian horror films as much as $33.3 \%$ of 48 respondents. Then followed by Danur as much as 23\% of 48 respondents. Pengabdi Setan (2017) is a remake of Pengabdi Setan (1982) and Danur is an adaptation of the novel Risa Sarawati with the same title.

Menurut anda seperti apa film horor yang baik dan menarik itu?

"What do you think of a good and interesting horror movie?"

Film horor yang diadaptasi dari novel karena bisa jadi gambaran visual dari gambaran imajinasi saat baca novelnya

Figure 6: People's Taste of Indonesian Horror Film Stories

"Horror film adapted from a novel because it can be a visual representation of imagination when reading novels"

Film horror yang terinspirasi atau bahkan dari real story masyarakat Indonesia sendiri, atau berasal dari mitos yang diceritakan turun menurun di daerah.

Figure 7: People's Taste of Indonesian Horror Film Stories

"Horror films that are inspired or even from true stories of Indonesian people, or come from myths that are told down and down in the area"

\section{Berikan saran anda untuk film horor Indonesia}

"Give your advice for Indonesian horror films" 
Menurutku perlu adanya cerita rakyat seperti dulu lagi ketika ada film Susana,sekarang pandangan film selalu luar negeri,sehingga citra rasa Indonesianya hilang,padahal kita punya kekuatan karakter dari cerita rakyat

Figure 8: Community Suggestions for Indonesian Horror Films Questionnaire

"I think there is a need for folklore like it used to be when there was a Susana film, now the film's view is always foreign, so that the image of Indonesian taste disappears, even though we have the strength of character from folklore"

Buatlah film horor dengan mengangkat tema urban legend di Indonesia. Karena cerita-cerita lampau itu diwariskan turun temurun. Sehingga anak muda masa kini bisa mengambil pelajaran berharga dari kisah-kisah tersebut

Figure 9: Community Suggestions for Indonesian Horror Films Questionnaire

"Make a horror movie with the theme of urban legend in Indonesia. Because the past stories were passed down from generation to generation. So that young people today can take valuable lessons from these stories"

The survey above shows that people are more interested in horror films that raise Indonesian urban legends because they can be considered valuable lessons for young people today who dominate the audience of Indonesian horror films. Also, horror films adapted from novels attract the audience because they are considered to be a visual description of the novel's readers.

From the data above, urban legend has become a cultural phenomenon that has been moved from people's lives into Indonesian horror films. The move of the urban legend from the Indonesian people's mouth-to-mouth story into an Indonesian horror film is a form of transit. While the change in value or meaning of urban legend from the people into Indonesian horror films is a form of transition.

Another example of the concept of transit and transition in Indonesian horror films. For example the process of transit and transition to female figures inIndonesian horror films. In real life, women are always identical with the impression of sensuality. But when women are shown in horror films, the impression of sensuality is slowly fading replaced by a mystical impression that makes the audience always guess the female character who appears in the film is a ghostly figure. This happens because in Indonesian horror films always show women as ghosts. 


\subsection{Creative Education and Critical Thinking through Repetitive Elements in Indonesian Horror Films.}

Deconstruction is a theory put forward by Jacques Derrida. The most interesting thing about Derrida's thinking is about how Derrida can describe and change human thinking towards the world. In changing thinking, according to Derrida it also means changing the narrative text, and the text itself is the reality of human life. This means that in changing reality one needs to first understand and describe that reality. The two concepts namely description / description (transformation) and transformation / transformation (transformation) can be combined into deconstruction. And deconstruction is ultimately an interpretation strategy (Madison, 1998).

If we return to the repetitive elements in horror films as the writer discussed earlier, when deconstructed using Derrida's theory, it will make repetitive elements in Indonesian horror films important because they can show creative education in society. For example, the author will show the results of the survey as follows:

Film horror indonesia akhir-akhir ini banyak yg menarik dan sanagat bagus, namun ada beberapa film horror yg editting filmya sangat kasar sehingga kesan horror malam menjadi keanehan dalam film dan menjadi buruk, dan juga banyak unsur Romantisnya sehingga kesan horror tidak terasa dan tidak tersampaikan ke audiens

Figure 10: Community Comments on Indonesian Horror Films

"Indonesian horror films lately many interesting and very good, but some horror films are editing films so rough that the horror impression becomes an oddity in the film and becomes bad, and also many elements of Romance so that the impression of horror is not felt and is not conveyed to the audience"

Terkadang film horor Indonesia terdapat unsur sedikit pornografi yang takutnya akan memberi efek buruk untuk anak dibawah umur

Figure 11: Community Comments on Indonesian Horror Films

"Sometimes Indonesian horror films have a slight element of pornography which fears they will have a bad effect on minors"

From these comments, the author tries to draw an anonymous conclusion, which is an appreciation of the current development of Indonesian horror films. Also, the anonymous highlighted the pornographic elements displayed by Indonesian horror films, which were deemed not good for minors. Then critical thoughts emerge along with the horror film on YouTube channels with criticism and review of the film's films. Like the following netizens comments:

"If the wound is inside, why are you bandaging, $f^{* *} \mathrm{k}$ lol" 


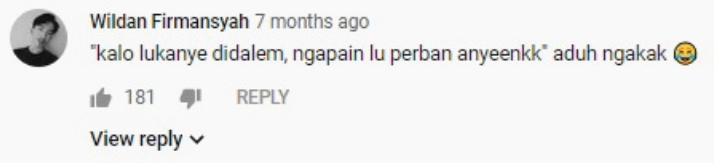

Figure 12: Netizen comments about Indonesian horror films on Youtube

Dajib muhyiddin 5 months ago

Mungkin film makernya sengaja membuat horornya bukan dari cerita dan hantu-hantunya. Tapi horor di aktingnya. Ih seremmmmm...

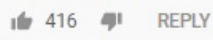

Figure 13: Netizen comments about Indonesian horror films on Youtube

"Maybe the filmmaker intentionally made a horror film, not from stories and ghosts. but the horror in the act. Creepy"

XoRoW Gaming 7 months ago

Ketika para petinggi perfilman bilang "dukung film indonesia", tetapi mereka tidak pernah berfikir menaikan kualitas dan terus mencari kuantitas atau cari aman. Apa lagi film horor yang lagi trend2 nya. bikin aj film durasi 10 detik, lampu rumah tiba2 mati trus ada suara dan jumpscare. gw yakin yg nnton bisa 200k lebih wkwkwkwk

16 $314 \%$ REPLY

View 4 replies $\checkmark$

Figure 14: Netizen comments about Indonesian horror films on Youtube

"When the film executives said: "support Indonesian films", but they never thought of raising the quality and keep looking for quantity or looking for safety. what else is a horror film that is trending. just make a 10-second film, the house lights suddenly turn off, then there's sound, and jumpscare. I'm sure those watching can be 200 thousand more"

From the three comments above, it can be seen that the community is very observant in paying attention to the development of Indonesian horror films, the community can evaluate the flaws in the film based on their tastes, reasoning, and experiences, this is where the critical thinking process occurs. Repetitive elements in Indonesian horror films can stimulate people to be able to think critically. Then creative education occurs when a director wants to listen and read the comments of the community, and then evaluate their work, so that the work in the future can become a better work.

\section{Conclusion}

Indonesian horror films have experienced ups and downs since their appearance and almost every decade has changed the concept. Starting from the horror film that lifts Indonesian urban legend to the elements of sexuality inherent in Indonesian horror films. 
There are a few things that are not considered in Indonesian horror films, namely less attention to the creative aspects of the story, but more on the storyline, cinematography, and repetitive performances, even impressed "template".

This phenomenon becomes interesting to do in-depth observations to find out how the repetitive element of Indonesian horror films as a medium of reflection and encourage critical and creative thinking. So that it can provide opportunities for cultural preservation and revitalization. By using theories from Maruska Svasek about transit and transition, then the viewpoint of Derridais also used to deconstruct repetitive thinking by film viewers to demonstrate the demythologization that occurs in horror films today.

Besides that, from the research method that the author uses, namely the study of literature on horror films through the Cincrybe YouTube account and comments that appear in the comments column, as well as a direct review of horror films that aired in 2017-2019, and digital questionnaires, we get data that Indonesian urban legend is a favorite of Indonesian people, age 17-25 is the age that dominates the audience of Indonesian horror films, and it turns out that people are very observant in observing the development of Indonesian horror films, people are able to evaluate flaws in films based on their tastes, reasoning, and experiences -mind.

From the data above, urban legend has become a cultural phenomenon that has been moved from people's lives into Indonesian horror films. The move of the urban legend from the Indonesian people's mouth-to-mouth story into an Indonesian horror film is a form of transit. While the change in value or meaning of urban legend from the people into Indonesian horror films is a form of transition.

Judging from Derrida's Deconstruction theory, repetitive elements in Indonesian horror films can stimulate people to be able to think critically. Then creative education occurs when a director wants to listen and read the comments of the community, and then evaluate their work, so that the work in the future can become a better work.

The results showed that the repetitive story culture was caused by the interest of Indonesian people about the legendary urban legend story. The use of urban legend as the main idea of the story, through the perspective of Svasek, creates attention to culture that provides opportunities for cultural preservation and revitalization.

\section{References}

[1] Sugiharto, B. (2013). Untuk Apa Seni?. Bandung : Matahari Press. 309- 310.

[2] Svašek, M. (2007). Anthropology, Art and Cultural Production. London: Pluto Press. 
[3] Ghaliyah, Bunga Dessri Nur. (2018). Sundel Bolong: Figur Mistis Gambaran Ideologi Patriarki. Dari https://www.jurnalperempuan.org/wacana-feminis/sundelbolong-figur-mistis-gambaran-ideologi-patriarki. Diakses pada 12 Januari 2019.

[4] Artanto, M. (2016). Mencermati Transit dan Transition dalam Arasemen Musik Nyanyian Negeriku Karya Singgih Sanjaya. Jurnal Kajian Seni, vol 02, Issue. 02, Pp: $132-150$

[5] Siswanto, J. (1994). Metafisika Derrida. Jurnal Filsafat UGM. Vol 18. Pp 8-14

[6] Yoesoef, M. (2013). Film Horor: Sebuah Definisi yang Berubah. Jurnal Wacana, vol. 5, issue 02. Pp 1-6

[7] Prawiranauli, Niken; A Irawan, Agusly; Wahjudianata, Megawati. (2018). Stereotipe Perempuan Indonesia Dalam Film Horror "Pengabdi Setan". Jurnal E-Komunikasi, vol. 6. Issue 02. Pp 1-12

[8] Sukatno S. M. (2016). Dedi; Bezaleel, Michael; Analisis Film Horor Indonesia Produksi Tahun 2014 (Studi Kasus: Mall Klender Dan Kamar 207), Jurnal Andharupa, vol. 2. Issue 1. Pp 1-14

[9] Khoirunnisa, R. (2012). Asosiasi Pornografis Dalam Judul- Judul Film Indonesia Bergenre Horor Dari Tahun 2008-2011. Jurnal Universitas Padjajaran. Vol. 1. Issue 1. Pp. 1-7

[10] Fiske, J. (2007). Cultural and communication studies. Yogyakarta: Jalasutra.

[11] Rusdiati, S. R. (2009). Film Horor Indonesia: Dinamika Genre. Publikasi Staff UI. Program Studi IImu Susastra FIB UI. Jakarta : Universitas Indonesia

[12] Crib, Cine. (2019). Roy Kiyoshi (The Untold Story), Ketika Cerita Ngawur Ketemu Akting Ancur - Cine Crib Vol. 225. Dari https://www.youtube.com/watch?v=VcJza9_fG0\&list=PLKow53WnFbTxGkRYSFJu9InC5Ksla8HE. Diakses 5 Juni 2018, pk 20.10

[13] Anisa, D.F. (2018). 2018 Bisa Menjadi Tahunnya Film Indonesia. Dari https://www. beritasatu.com/hiburan/475493/2018-bisa-\{\%\}20menjadi-tahunnya-film-indonesia. Diakses 10 Mei 2019, pk 21.11 